\title{
(MIS)MANAGING LABOUR MARKETS? THE DECLINE OF THE CONTEMPORARY GLOBAL LABOUR MARKET FOR BRITISH SEAFARERS.
}

\section{Dr. Shaun Ruggunan: School of Management Studies, University of KwaZulu-Natal}

\author{
Key words: seafarers, globalisation, labour markets, maritime
}

Purpose: The purpose of this article is to investigate the ways in which states are still significant actors in creating and shaping the nature and characteristics of global labour markets. My argument is demonstrated through an empirical case study of the global labour market for British seafarers.

Problem Investigated: The last 30 years has witnessed a decimation of the number of employed British seafarers, particularly at lower rank levels, such as ratings. I contend that despite Britain's long and rich maritime history, the British state has not acted meaningfully to reverse the decline of British seafarers. The lack of meaningful action I contend is an attempt to crew British owned ships with cheaper seafaring labour from Asia, particularly south east Asia. In so doing the British state has contributed to the decline of a once thriving labour market. There has simultaneously been an upsurge in the employment of seafarers of other nationalities, and thus the creation of new labour markets in countries such as the Philippines. This paper is an attempt to understand some of the factors responsible for the decline of the British labour market for seafarers.

Methodology and Approach: This paper is the outcome of a larger qualitative study undertaken for my doctoral thesis in industrial sociology which examined the transformation of the global labour market for South African, Filipino and British seafarers. The methodology consists of in depth interviews with maritime officials and trade union leaders. These were conducted in person in London, United Kingdom between 2005 and 2008. These interviews are supported by extensive literature and documentary research, to validate, support and test claims made by my interviewees.

Implications and Value of the Research: The theoretical contribution of this paper is to reinsert the state more critically into the literature on labour markets. Empirically, seafaring labour markets are largely ignored by the disciplines of both sociology and commerce. The paper attempts to fill this gap by investigating a much neglected occupational sector. Very little empirical work is being done by South African researchers on global labour markets outside South Africa. This paper is therefore primarily addressed to a South African audience.

Conclusion: The paper demonstrates that the state has to be a willing and active partner in ensuring employment security of its worker-citizens in global labour markets. The private sector and organised labour by themselves are unable or unwilling to prevent massive job losses without state intervention. As increasing numbers of workers join global labour markets, states need to become more involved rather than less involved in ensuring the stability of employment for their citizens.

\section{INTRODUCTION}

The aim of this article is to demonstrate the state's role in managing, creating and shaping the nature of global labour markets. This is done through a case study of the labour market for British seafarers in the merchant navy. The article argues that despite claims that states are no longer powerful actors in a globalising world, national states continue to be significant actors in managing flows or flights of capital and labour. The decimation of the labour market for British seafarers epitomises the ways in which states, and in this case the British state, actively prioritise foreign labour interests over national labour interests. In so doing new labour markets are created and old ones destroyed. The tendency in mainstream management and labour studies (Tilly \& Tilly, 1998; Silver, 2006) is to focus on the roles of capital and organised labour in creating and shaping labour markets. This empirical case study shifts the focus to the role of states in this process and demonstrates that states are also significant contributors to the creation and decimation of labour markets. 


\section{THE LABOUR MARKET FOR BRITISH SEAFARERS}

The changing nature and characteristics of the global labour market for British seafarers must be understood in the context of broader changes in the British merchant navy. This section examines the broad changes in the British shipping industry such as the decline in registered and owned British merchant navy vessels and its subsequent impact on the employment of British seafarers at both the officer and ratings ranks. Ratings are considered to be the working class of the shipping industry. They include workers that perform a range of unskilled and lower skilled job functions. These range from being a cook to an able bodied seaman. Ratings may perform lower skilled engineering functions as well. Officers on the other hand perform more skilled and complex engineering and technological functions. Officers need at least an undergraduate degree to qualify for service. Historically, Britain's merchant navy and seafarers dominated key global trade routes. However, this dominance began changing most notably in the 1970s and rapidly in the 1980s (Lane, 1986, Ruggunan, 2001, 2009).

The trends in the British maritime industry since the 1970s are marked by:

1. A steady decline of a British owned and registered fleet ${ }^{1}$ (more so than other European Union countries).

2. A sharp decline in the number of employed British officers and ratings.

3. A significant decline in the annual throughput of ratings and cadets through maritime education and training institutions.

4. An ageing British seafaring pool and hence a dwindling skills pool.

Figure 1. British Officers and Ratings Serving in the Merchant Marine from 1980 to 1997

\section{UK officers $=$ UK Ratings}

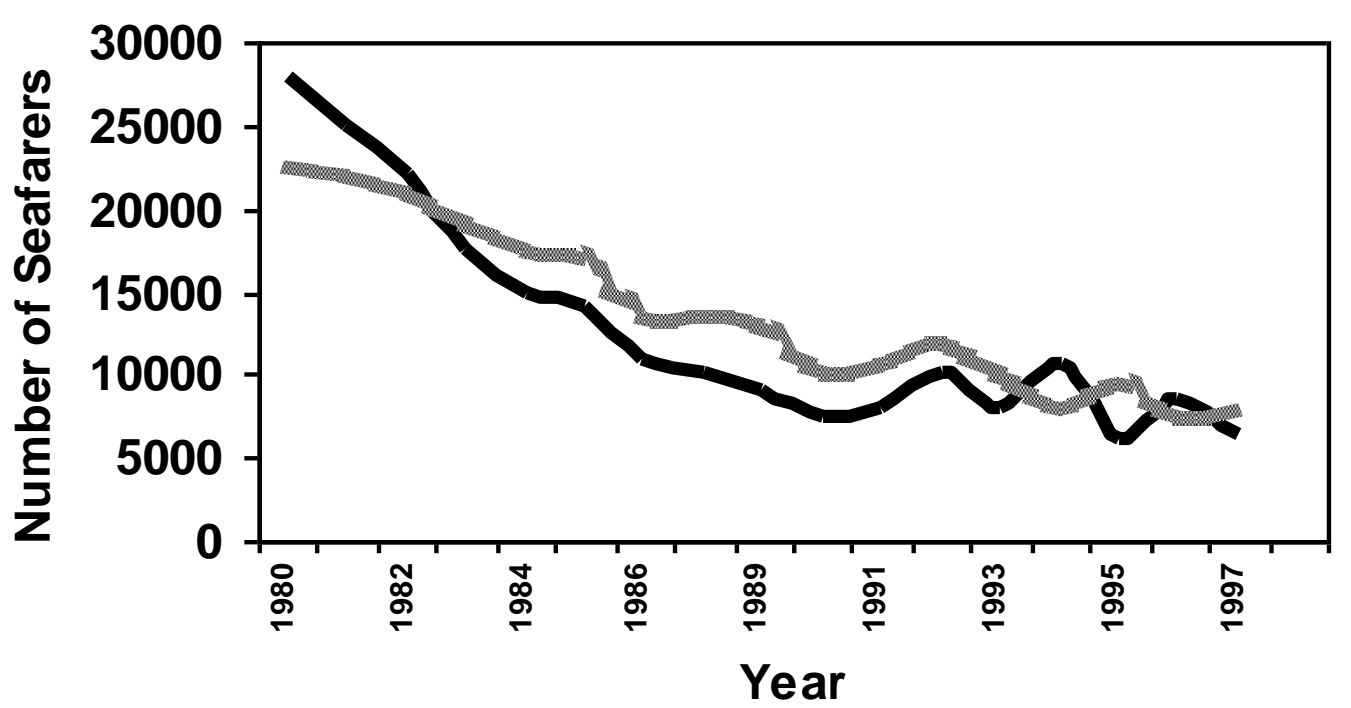

Source: Department of Transport Merchant Fleet Statistics: 1980-1997 (11)

Figure 1 shows a contraction in the number of ratings from approximately 22000 in 1980 to just over 5 000 in 1995. UK officer numbers fell from 28000 in 1980 to 10000 in 1995. These statistics were provided by the British Chamber of Shipping in 1995 and are based on the number of British seafarers employed by their 125 members that operate 730 merchant ships (Chamber of Shipping Annual Reports 
1996). Further, 80 percent of British ratings employed by Chamber of Shipping companies during this period worked on United Kingdom registered fleets (Prescott, 1999: 11). However, only 55 percent of British Officers worked on United Kingdom registered fleets. This highlights the two tier nature of the labour market for seafarers in general and British seafarers specifically. It implies that British ratings' employment is closely linked to United Kingdom registered and owned fleets but that officers have greater mobility in negotiating employment in the labour market between foreign owned and United Kingdom owned fleets. This is due to the shortage of officers in the global labour market as well as the preference for British officers (over other nationalities) by foreign shipping companies in general.

In 1997, the London Guildhall University Study was commissioned by the United Kingdom government to conduct an analysis of the labour market for British seafarers in the merchant navy (McConville et al, 1998). Their findings, whilst still worrying, indicated that the projected decline was not as sharp as projected by the Chamber of Shipping from 1996 to 1997 . The study found that in 1997 there was a total number of 28000 active (i.e. employed) British seafarers. Of these, 17140 were officers and 10860 were ratings. A further 1130 officer cadets were undergoing training. However, when a retirement age of 57 was applied to this sample, the total number of active seafarers fell to 25460 . The decrease only occurred at the officer level, where numbers fell from 17140 to 14600 (McConville et al,1998 Annex B). The study also reflected an ageing workforce with 71 percent of officers being between the age of 40 and 65 , whilst 53 percent of ratings were in this age bracket. The study further projected that, in order for the number of British officers to recover, training of officer cadets would have to be sustained at throughput levels of 1000 new officer cadets a year. However the 1998 intake of cadets at United Kingdom maritime institutions was only 450. The 1997 study concludes that unless interventions are made in the fiscal policies governing ship registration and maritime training policies, the available seafarer labour pool would decline at 6 percent a year.

The United Kingdom government, in response to the possible decimation of British seafarers as projected by the various studies, implemented a tonnage tax scheme in 2000. Since 2000 the United Kingdom registry has increased by 250 percent. The national British fleet is now the second largest in the European Union, topped by Greece (Chamber of Shipping Annual Report, 2005/6). Linked to the tonnage tax scheme is a unique training and skills development plan. In order for a shipping company to benefit from the new fiscal scheme, it must train one officer for every fifteen it employs. According to the Minister of Transport, at the implementation of the tonnage tax in 2000-2001, there were 896 United Kingdom officers employed on tonnage tax ships. In 2006 this rose to 2888 . The number of ratings for the same period rose from 449 to 1460 .

British trade unions, the National Union of Marine, Aviation and Shipping Transport Officers (NUMAST) and the Rail and Maritime Union (RMT) are, however, not as convinced. ${ }^{2}$ They argue that of the 29000 seafarers that were considered active in 2008 by the government only 26000 were employed at sea. They have further commented that whilst the new tax scheme has done wonders for shipping companies, it has in no significant way reversed the decline of British seafarer employment. Dr Stephen Ladyman, Minister of State for Transport, has pointed out that the number of active seafarers has increased from 25 000 in 2001 to 29000 in 2006 (McCaskey, 2007:21). Of these, 10000 were ratings with officers numbering 19000 . This reflects an increase in the number of British officers but no significant difference in the change to the number of active ratings. Further, the age profile of officers means that rather than rapidly expanding its pool of officers, the number of United Kingdom officers will actually plateau and then decline by almost 10000 over the next fifteen years. ${ }^{3}$

The RMT information officer argued that the numbers of active ratings are far less than the 10000 indicated by government and the Chamber of Shipping. He estimates it to be 8000 . He further points out that only 40 to 50 British ratings were trained and employed into the merchant navy in 2004-2005.

What emerges from the developments in the United Kingdom shipping industry and labour market for seafarers is that, whilst changes in shipping taxation schemes have benefited shipping capital enormously, seafaring labour remains precarious, particularly for ratings. My further investigation into how this was being dealt with at governmental level was particularly revealing as is exemplified by this quote: 
"Despite all the good intentions, the tonnage tax exemption is not a success for United Kingdom ratings. So although shipping companies must train officer cadets there is no legal requirement to employ officers or ratings; indeed, there is no obligation even to train United Kingdom ratings - companies must simply consider United Kingdom ratings training and employment options. Unfortunately the majority of vessels that enter the United Kingdom register employ no United Kingdom seafaring ratings."

(Clark, April 2006: House of Commons Debate, Column 257WH).

In responding to this challenge the Rail and Maritime Union has embarked on a project to find alternate employment opportunities for UK ratings. ${ }^{4}$ The Rail and Maritime Union argues that the fight to preserve and increase the number of jobs for ratings is perhaps not the best strategy to service their ratings membership. The high cost of British ratings as reflected in Table 1 below reflects the deterrent cost factor in hiring British ratings in comparison to other nationalities.

Table 1: Monthly On-board Earnings for Ratings in 2008 (US\$)

\begin{tabular}{|l|l|l|}
\hline Country of Domicile & Dry Cargo & Tanker \\
\hline United Kingdom & $3300-3960$ & $4620-4950$ \\
\hline Russia & $1330-1485$ & $1485-1595$ \\
\hline South Africa & $1430-1650$ & $1650-1950$ \\
\hline China & $900-1100$ & $1060-1320$ \\
\hline Croatia & $1430-1485$ & $1430-1485$ \\
\hline India & $1280-1485$ & $1335-1485$ \\
\hline Montenegro & $1420-1485$ & $1485-1595$ \\
\hline Philippines & $1155-1485$ & $1210-1485$ \\
\hline Poland & $1210-1485$ & $1540-1650$ \\
\hline Romania & $1210-1485$ & $1430-1650$ \\
\hline Ukraine & $935-1045$ & $1045-1155$ \\
\hline
\end{tabular}

Source: International Shipping Federation, 2005

Further, the RMT argues that most British ratings are not even working on deep sea vessels. Of the estimated 10000 British ratings currently employed, 4500 work in deck and engine departments of non deep sea vessels. The balance are employed on cruise ships, short ferry services and the offshore oil sector, research vessels, coastal tankers and chartered services (Chamber of Shipping Report, 2006: 1). The number of British ratings employed in foreign flagged vessels is negligible. ${ }^{5}$

The RMT is exploring alternative employment opportunities for ratings that range from increased work on ferries to shore based work as well as possibilities to upgrade to officer levels. ${ }^{6}$ In conjunction with this locally based strategy is a campaign by the Rail and Maritime Union within the International Transport Workers Federation to secure and protect United Kingdom ratings' jobs. 


\section{THE UNITED KINGDOM: A REVERSAL OF FORTUNE? ${ }^{7}$}

This section deals with the impact that two British state agencies have on labour market restructuring for British seafarers in the global labour market. These are the Maritime and Coast Guard Agency (MCA) and the Department of the Environment, Transport and the Regions (DETR). Of special interest in the DETR is the functioning of the Shipping Working Group Sector (SWGS). The DETR provides mainly a research and policy function whilst the Maritime and Coast Guard Agency is tasked with implementing such policies. In addition, the MCA is responsible for implementing the 2000 British Tonnage tax scheme as well as administrating the compulsory Support for Maritime Training Scheme (SMART) for British seafarers. $^{8}$

The DETR is particularly interested in rebuilding the British national fleet, whilst simultaneously wanting to reconsolidate a significant pool of British ratings and officers. However, it increasingly appears that in order for a national fleet to make a profit, British ship owners must enjoy access to cheap flexible labour so as to maximise operational profits. ${ }^{9}$ The agency therefore has to maintain a fine balancing act between the needs of labour and those of employers. The agency engages in two strategies. Firstly, it has addressed fiscal policies affecting shipping registration in an attempt to grow a national fleet through the implementation of a tonnage tax scheme in 2000. Secondly, it has aimed to attach a training condition to ship owners that opt for a tonnage tax scheme. This training condition is known as SMART in the industry and obliges ship owners opting for tonnage taxation to provide berths for British cadets. ${ }^{10}$ The academic training would be subsidised by government up to an amount of 50 percent. The condition of registration for tonnage tax is that a company can register for a period of ten years provided they sponsor or provide the training for one British officer each year for every 15 deck or engineering officers of their existing sea based staff complement (Gardner et al, 2008). The Smart Training scheme was introduced in 1999/2000. This scheme superseded previously more generalised training schemes such as the Government Assistance Training Scheme and the Development of Certificated Seafarers Scheme.

\section{PROVISIONS OF THE BRITISH TONNAGE TAX SCHEME ${ }^{11}$}

There are four main provisions of the British tonnage tax scheme. It is important to note however that it is an optional fiscal regime. The main incentive for ship owners to choose this regime is the potential massive savings in taxation since they are taxed on tonnage of their ships instead of profits. The taxation scheme does not dictate the nationality of seafarers or wage rates that have to be paid by ship owners electing to be taxed under this scheme. The reason that it is not a compulsory taxation method is because certain sectors of the industry or certain companies may find that they would actually pay more tax under a Tonnage Tax regime than they had previously. For example, a shipping group may have continuing losses (possibly as a result of capital allowances) which it currently surrenders as group relief to profitable, non-shipping, members of the group - under Tonnage Tax there would be no shipping losses to surrender, and as a consequence there would be tax to pay. Once a shipping company decides to avail itself of the tonnage tax scheme, it will do so for a ten year period with the option to renew for another ten years.

Firstly tonnage tax is an alternative way of computing shipping profits and losses. Participating companies will have their taxable profits from shipping based on the tonnage of the ships they operate, rather than by reference to their actual business profits. The 'relevant shipping profits' are replaced by the 'tonnage tax profit' (per paragraph 2 of the Act), which will be chargeable to corporation tax in the normal way. Where trading profit would be relevant shipping income, any loss accruing to the company is similarly left out of account for the purposes of corporation tax, as will capital losses (subject to time apportionment) on the disposal of tonnage tax assets (Tonnage Tax Maritime Report), 2001:1600).

Secondly there is a training requirement. "Participating companies will also have to sign up to 'a minimum training obligation' for the training of seafarers. This is designed to secure industry 'best practice' levels of training and is a key element in the Government's long-term policy to regenerate the nation's maritime skills base. The Department for Transport administers the training requirement" (TTM, 2001:1600). 
Thirdly it is a 'Ring-fenced' regime. Tonnage Tax fixes the level of a company's taxable profits from shipping but not from any other activity.

Fourthly, in addition to this there is "a sweep-up anti-avoidance provision to deter deliberate serious or repeated abuse of the regime. This has been put in place with the agreement of the shipping industry. It would be contrary to Parliament's intention for a company to enter into transactions that enable the benefit of Tonnage Tax to leak out beyond the shipping industry. If a company or group of companies seriously misuses Tonnage Tax in this way, then there is power to expel it from the regime with additional penalties" (TTM, 2001:1600).

\section{CALCULATING TONNAGE TAX PROFITS}

Gross tonnage is used when deciding whether a ship is qualifying, for which it must be 100 gross tons or more whilst Net tonnage is used in the actual calculation of tonnage tax profit. The legislation provides for a calculation of the tonnage tax profits in four steps, although in practice the stages may be combined.

\section{Step One - the daily profit}

Determine the daily profit for each qualifying ship by reference to the following table:

\begin{tabular}{|l|l|}
\hline For each 100 tons up to 1000 tons & $£ 0.60$ \\
\hline For each 100 tons between 1000 and 10000 tons & $£ 0.45$ \\
\hline For each 100 tons between 10000 and 25000 tons & $£ 0.30$ \\
\hline For each 100 tons above 25000 tons & $£ 0.15$ \\
\hline
\end{tabular}

For example, the daily profit of a ship with a net tonnage of 17371 tons would be $£ 68.40$, made up of:

$\begin{array}{llll} & 10 \times £ 0.60 & = & £ 6.00 \\ \text { Plus } 90 \times £ 0.45 & = & £ 40.50 \\ \text { Plus } 73 \times £ 0.30 & = & £ 21.90\end{array}$

\section{Step Two - ship's profit for accounting period}

Multiply the daily profit by the number of days in the accounting period, or, if operated for only part of the period, by the number of days in that part.

For example, if the ship mentioned above were operated for the whole of the accounting period ended 31 December 2003, the ship's profit for that accounting period would be $£ 7993$ ( $21.90 \times 365$ ).

The reasons that the tonnage tax scheme managed to increase the number of ships registered under the British flag but not the number of British seafarers employed is fivefold.

Firstly, whilst there is a mandatory training link for companies that elect to be taxed under this system, there is no mandatory employment link. In effect British cadets and ratings are trained but once training is completed, they prove to be too expensive for employment in the global labour market. Secondly, a number of ships that have shifted to the British flag are Asian owned (for example, Evergreen and HatsuMarine), and use the British flag (under the tonnage tax scheme) as a flag of convenience. Further there is no compulsion for these companies to hire British seafarers as a condition of flying a British flag and these ships are crewed by cheaper Asian labour. Thirdly, ship owners are given an option of Payment in Lieu of Training or PILOT, which means that if companies cannot train their own cadets or ratings they have to pay PILOT. Many shipping companies find it cheaper to pay PILOT than to source, train and provide seatime to cadets. Fourthly, given the oversupply of ratings in the global labour market, it makes very little sense to train more ratings, British or otherwise who are too expensive relative to other equally 
qualified ratings. The British government is reluctant to impose or make mandatory an employment link which is what British seafaring unions are arguing for. Fifthly, the profession or career has fallen out of favour as reflected in the dwindling number of new recruits in the industry. There is thus a dwindling pool of incumbents to draw on for training purposes. I expand on these arguments in the section below.

\section{THE FAILURE OF SMART TO CREATE EMPLOYMENT}

In theory, SMART is an excellent training initiative and one that the South African government is advised by the Transport Education and Training Authority (TETA) to implement to meet the training needs of its own maritime industry. However, as interviews with the National Union of Marine, Aviation and Shipping Transport Officers (NUMAST) and the Rail and Maritime Union (RMT) officials revealed, there are some deep concerns about the training scheme. ${ }^{12}$ The unions allude to three problems with SMART. Firstly, there is no clear employment link. Whilst the provision of seatime or berths allows a cadet to qualify as an officer, the ship owner is under no legal obligation to employ cadets they train, "...greatly reducing its effectiveness." ${ }^{3}$ Secondly, it focuses exclusively on officer training, whereas RMT would prefer a focus of the scheme on upgrading ratings skills to make them more employable. ${ }^{14}$ Thirdly, the percentage of the subsidy given towards the academic training of cadets remains contentious, with NUMAST wanting a 100 percent subsidisation of the training costs. ${ }^{15}$

The tonnage tax scheme has been very successful in attracting ships back to the UK registry but the SMART training scheme has had a more modest success. Both unions are not entirely convinced that the SMART scheme represents a sincere and concerted effort by the DETR to reverse the decimation of British seafaring jobs since the 1970s. SMART is even alleged to be a means of pacifying the unions into accepting the inevitable total decline of British seafarers employed on flag of convenience (FOC) deep ocean going ships. According to NUMAST, the introduction of a tonnage tax scheme since 2001 has seen a growth from 42 to 67 shipping companies now using the national British registry and from 2000 to 2003 , a total of 745 ships had joined the national registry. This is up from 520 ships pre-2000. However, as a NUMAST official mentioned at a 2008 interview with me in London, it is difficult to assess the full extent of the success of the tonnage tax scheme since not enough time has elapsed to judge properly and registries require decades to reach maturity.

The most disappointing aspect of the revised fiscal legislation was the lack of delivery from the training scheme. In this sense both unions allege that the DETR and the British treasury benefited the most from the tonnage tax scheme whilst British seafaring labour experienced no or very few benefits. In fact, the number of British officers employed on British registered ships actually fell by almost a third from 2000 to $2003 .^{16}$ The DETR statistics bear this assertion out. In 2001, 69 percent of British officers worked on British registered ships, in 2002-3 this figure was 58 percent and in 2004-2008 it declined even further to 49 percent. This problem is compounded by the fact that the profile of British officers is 'unhealthy'. Almost 70 percent of British officers were over 40 years old in 2008, with more than 80 percent over 35 years old. This, as my interviewee claimed, presents a generation gap. He explained that Britain lost a generation of seafarers in the 1980s and government's attempts to redress this issue is, to quote my source, 'half hearted'. ${ }^{17}$

An emerging and disturbing trend for RMT and NUMAST but less so for the Maritime and Coastguard Agency (MCA) is the number of foreign junior officers that are now working on ships that used to employ a 100 percent British crew. An analysis of statistics provided by the MCS, shows that the number of Certificates of Equivalent Competency issued to non British seafarers by the agency in 1997 was 37 . The number of certificates issued in 1999 was 2000. The total number of certificates issued from 1997 to 2001 was 6097. A NUMAST Report (2003: 9), authored by its general secretary, asserts that:

"...even if the British fleet recovered substantially by some miracle in the next year, it would take more than ten years to train and employ a new generation of British seafarers. As it is, the majority of masters on UK ships are British but at the lower ranks such as engineer officers, second officers and chief officers other nationalities are creeping up." 
The Seafarer International Research Centre (SIRC) data on crewing levels of British ships substantiates this assertion. The data reveal that 70 percent of masters on UK flagged ships are British, but only 54 percent of chief engineers, 37 percent of chief officers and only 33 percent of second officers respectively are British. The logic of these employment patterns implies that over a period of time, perhaps 15 years, other younger nationalities that occupy these junior officer ranks will progress to officer levels, obliterating British dominance of the labour market for officers. The NUMAST Report of 2003 (7-8) indicates that Filipino and Chinese seafarers could be the next (but not the last) generation of officers to dominate the world's merchant marine.

\section{THE GOVERNMENT STRATEGY TO SEEK ALTERNATIVE SHORE BASED MARITIME EMPLOYMENT FOR RATINGS AND OFFICERS}

To reiterate, Britain has experienced the displacement and loss of jobs for ratings and officers since the latter part of the 1970s. Despite strategies by trade unions and the British state to reverse this displacement and massive job loss, both have continued. The British DETR and British seafaring trade unions like NUMAST and RMT have acknowledged that subsidisation of officer training through the SMART scheme and the mandatory guarantee of training berths to cadets by ship owners wishing to enjoy the benefits of the UK tonnage tax regime have not delivered on their promises of job creation and employment. The introduction of tonnage tax has been a modest success for the employment of British seafarers, but exclusively benefitting cadet officers. An alternative proposed by NUMAST and RMT and later actively endorsed by the DETR as a viable strategy is the redeployment of UK seafarers into shore based employment.

In 2003 the DETR commissioned a study on the United Kingdom economy's requirements or people with experience of working at sea. The aim of the study was to estimate the demand for seafaring skills and experience in maritime shore based jobs in the United Kingdom. These jobs include jobs in port services, maritime law firms, marine insurance, ships' agents, maritime schools, consultants and surveyors, terminal operators, towage and salvage, ship finance, ship brokers and charterers, marine equipment and information technology, marine engineering, and ship and crew management. The study found that 15 700 jobs required the skills of former seafarers, where employers considered seafaring experience an essential prerequisite to the job (Gardner et al, 2003:7). The annual demand for these types of jobs was predicted to grow on an average of 700 jobs a year. The difficulty for employers arises when the demand exceeds the supply of seafarers, especially officers. In such instances, there will be a lack of a British pool of officers from which to recruit staff for essential shore based maritime work.

\section{As the DETR (2003:45) report states:}

"...it is inevitable that a shortfall in the supply of UK ex merchant navy officers to fill vacancies in shore-based jobs for which their seafaring experience is considered essential, will occur between now and the year 2011. Since the pool of UK ships' officers to fill these positions was determined by recruitment levels over the past fourteen to twenty nine years, the die was cast long ago and there are only a few measures that can be taken to increase supply in the short term without increasing wastage from the pool above its natural level."

If such a scenario plays out, then shore based maritime jobs may be staffed by non British seafarers, effectively consolidating the displacement of essential land and sea based maritime jobs for British seafarers. Another option could be to train non seafarers to make up for the supply shortfall, although such a move raises issues of quality, duplicating training costs, and does not address the issue of sectors where employers regard seatime as an essential experiential requirement for shore based maritime jobs. Most shore based industries would balk at the idea of financing such sea based training on their own (Gardner et al, 2003).

Since the publication of the Report in 2003, the DETR has chosen not to raise the subsidisation level of cadet officers on the SMART scheme. After acrimonious discussions with NUMAST, the DETR chose not to implement a mandatory employment link to the SMART scheme. ${ }^{18}$ The state is currently developing a set of policies in conjunction with RMT and NUMAST to actively encourage ratings to seek employment in maritime sectors other than the merchant marine. Given the almost limited existence of British ratings 
working on FOC ships, it seems that the displacement of these jobs is a completed exercise that will continue to resist attempts to reverse the displacement. The strategy adopted by the state seems to be one of accepting the displacement but attempting to circumvent job loss by redeploying ratings into a number of alternative maritime sectors.

RMT's comment and insight into this situation is one of recognition that redeployment may be the only viable strategy though not the most ideal one. As one RMT official comments:

"Yes, we work very well with NUMAST and our negotiations with the DETR can get quite heated but they include us on all their committees especially the shipping working group. We fought hard for the tonnage tax...it was a victory for us but now instead of creating employment the DETR says we must redeploy, ...Well we didn't like it at first but rather than that our members be jobless we explored the strategy, a job is a job. But what about national pride, history and all that, the DETR has forgotten. There are some good guys there but you know we have to accept the reality I suppose, the DETR is not going to force employment of British seafarers, we are going to ask the ITF to impose quotas on ship owners to hire British seafarers, at the congress in your city, Durban in August 2006, but in the meantime our strategy is to sit on all the shipping committees at the DETR and find alternative marine jobs for our members". ${ }^{19}$

My insight and sense of NUMAST and RMT positions and policy based on interviews and analysis of their policy documents is that their appeal to the DETR is a very emotional one that hearkens back and draws on Britain's imperial past ${ }^{20}$ as imperial maritime power extraordinaire, which is not the most convincing argument to capture the state's attention. Both unions also argue for further training, but without guaranteed berthings and employment offers it amounts to training for unemployment. A further issue is the cost of labour. Crudely put, British seafarers are too expensive to be employed on FOC ships. This is a global reality borne out by over a decade of research and is reflected in the practice of ship owners and crewing agencies. Dr. Bin Wu, (a researcher at the Seafarers International Research Centre, at the University of Cardiff), said in one of our discussions that NUMAST and RMT are 'resisting globalisation since it's not on their terms'. Whilst that comment may be hyperbole, the evidence indicates that is a level at which the unions feel completely disempowered by the global changes in the shipping industry and its impact on the British labour market. Modest support from the state and a more pragmatic attitude and preference by British shipping companies for lower cost seafarers has compounded the problem. The state, by advocating and campaigning for a redeployment strategy as opposed to a convincing job creation campaign, is influencing and determining the characteristics of the current and future labour market for British seafarers.

The situation for officers, whilst less dire, is still a cause of concern. A failure to make up for the loss of a generation of officers and the subsequent high age profile of British officers, has alarmed the British state sufficiently for it to explore alternative employment opportunities for British officers in offshore maritime sectors. It considers this to be a more viable strategy than to explore or implement more interventionist policies on shipping companies to employ British seafarers.

The unions, whilst working closely with the state in an advisory capacity on the alternative employment policy, are nonetheless not completely satisfied or convinced that the DETR is doing 'all it can' to reverse the decline. As general secretary Brian Orrell of NUMAST asserted in a NUMAST Report (2003:12):

"For us the issues to be addressed are obvious enough. Government needs to ensure an enhanced flow of skilled and experienced maritime personnel. Since 2000, we have welcomed the government's maritime policies but it seems like only ship owners have benefited and we are not any better off, or just a little better off when compared...over the past year in particular we have lost so many jobs. From October 2001 to March 2004 NUMAST has had to deal with 1,100 declared UK officer redundancies (a figure that resulted in some 719 confirmed job losses following negotiations between the Union and employers). We believe that the government must finish the job they started with tonnage tax in $2000 . "$ 
This view is echoed and expanded on in the NUMAST publication, A NUMAST Report on UK Seafarers, Maritime Skills and the Tonnage Tax, which was released in 2008, and categorically states its unhappiness with government's strategy in dealing with what it terms an employment crisis facing British seafarers. The evidence points to a further displacement and job losses for British officers as the existing cohort ages and natural attrition occurs.

RMT's analysis is similar as is articulated by the comments made below:

"The thing is we have a government that basically does not want to piss off ship owners. That's why they throw us a bone with the SMART training but won't introduce a compulsory employment link. This has been happening since the 1980s that our seafarers have been losing jobs. So they don't even care that if we had another Falklands war, that's heavily maritime based, there won't be enough qualified ratings or officers to man the navy ships. They say it's the new reality of the world and we must accept it and be more creative, just you see, even the port jobs will go to foreigners soon... the tonnage tax has been good, it was a good first step, but how shall we say, its impact on seafarer employment has been modest to say the least. We thought with a Labour government, it will all change, but the pressure from business, mainly from the chamber of shipping, is too much on government. It's one thing to have to fight the ship owners and now we have to fight our own government." 21

Training with no compulsory employment link, whilst part of a solution, is not sufficient to span the loss of a generation of officers. The state, whilst working closely with seafaring trade unions to protect and preserve job losses and prevent further displacement has channelled its interests in exploring employment possibilities for seafarers outside the merchant marine. It is reluctant to intervene more directly in the industry and labour market by making the hiring of British officers compulsory. Its intervention in introducing a tonnage tax scheme in itself may be seen as a state that is more capital friendly than labour friendly as the unions assert, or a more pragmatic decision taken by a state that prides itself on free marketism. An increasingly possible scenario is that over time, British officers will disappear from their traditional jobs on ships in the global merchant marine in the same way that British ratings have lost their jobs and been displaced from that sector. This will fundamentally alter the nature of the labour market for British seafarers in the global labour market, in fact erasing such a market. The fading away of British officers will possibly result in the 'newer' global seafaring supply countries such as the Philippines, Russia, Ukraine, China, India, Pakistan, Canada and a handful of eastern European nations becoming the new suppliers of junior and senior officers. Such a transition is likely to take place over the next decade, and will consolidate the restructuring and transformation of the seafaring labour market that first began in the 1970s. This is not to imply a foresight of capital in erasing expensive labour from its operating cost structures, but rather recognition that in the cyclical nature of capital, operating and labour costs are often paramount. By actively not choosing to employ British officers because of their high costs, compounded by a diminishing pool of British seafarers to employ from, ship owners, are unlikely to campaign for the protection of expensive jobs. The British state does not want or appear to be protectionist or interventionist in this regard by resisting "inevitable" globalising processes. Instead it is exploring strategies of redeployment of British seafarers into non merchant navy employment whilst monitoring the growth of its national register since the introduction of tonnage tax in 2000.

\section{CONCLUSION}

This article has examined the role of state agencies and the ways in which they have influenced the nature of global and national labour markets for their (and implicitly seafarers of other nationalities) respective seafarers. The article demonstrated that whilst changes in the shipping industry and its labour market have occurred globally, the unique processes of national states, such as the United Kingdom, remains a significant shaper of labour markets. The case of British seafarers shows that without the support of the state, any initiatives by unions to restructure labour markets will most likely fail. British state agencies responsible for seafarers are reluctant to be directly interventionist in the shipping industry to reverse the decline of British seafaring jobs. Instead they have spearheaded initiatives to redeploy British ratings into shore based maritime jobs. The government whilst supporting union calls for training initiatives has chosen not to support a call for a quota system, forcing ship owners to employ non-British 
seafarers. It appears very much that there will be no reversal of fortune for British seafarers in the merchant navy. The state continues to be a significant player (deliberately or not) in global processes and global labour market formation.

\section{ENDNOTES:}

${ }^{1}$ Whilst the British fleet that is registered and owned in Britain has declined, it nonetheless comprises 6 percent of the world's merchant shipping or 449 vessels. In addition, 368 British-owned ships are registered in Flag of Convenience registries and 215 British-registered ships are foreign owned. The ownership of these 215 is as follows: Australia 3, Denmark 46, Finland 1, France 4, Germany 76, Greece 7, Ireland 1, Italy 4, Netherlands 3, Norway 36, NZ 1, South Africa 5, Spain 1, Sweden 15, Switzerland 3, Taiwan 1, Turkey 2, US 6 . The 368 that are flagged out belong to the following registries: Algeria 13, Antigua and Barbuda 7, Argentina 4, Australia 2, Bahamas 69, Barbados 5, Belgium 2, Bermuda 9, Brazil 1, Brunei 8, Cape Verde 1, Cayman Islands 10, Cyprus 6, Denmark 1, Finland 1, French Southern and Antarctic Lands 1, Georgia 4, Gibraltar 4, Greece 9, Hong Kong 43, India 1, Indonesia 2, Italy 3, South Korea 2, Liberia 41, Malta 8, Marshall Islands 12, Morocco 1, Netherlands 19, Netherlands Antilles 3, Norway 6, Panama 37, Papua New Guinea 6, Saint Vincent and the Grenadines 13, Singapore 9, Slovakia 1, Spain 1, Thailand 2 and Tonga 1. The United Kingdom therefore continues to be a major player in the commercial maritime industry. The Merchant Marine has, since 1993, vacillated between the fourth and fifth biggest service-sector exporter for the United Kingdom (Prescott, 1999). This underlies its significance to the British economy and the need to urgently address the labour problems facing the shipping industry.

${ }^{2}$ Interview, RMT Information Officer, London, United Kingdom: June 2008.

Interview, NUMAST Information Officer, London, United Kingdom: June 2008.

${ }^{3}$ Interview, NUMAST Information Officer, London, United Kingdom: June 2008.

${ }^{4}$ Interview, Rail and Maritime Union Information Officer, London, United Kingdom: June 2008.

${ }^{5}$ Interview, RMT Information Officer, London, United Kingdom: June 2008.

${ }^{6}$ Interview, RMT Information Officer, London, United Kingdom: June 2008.

${ }^{7}$ Attempting to obtain interviews with the DETR and MCS in the United Kingdom proved extremely difficult, with a range of forms needed to be filled in. Both the DETR and MCS are considered essential security providers for the national security of the United Kingdom and, as they informed me, especially post 2001 are reluctant to provide interviews. Such was their emailed response to my queries, and despite me providing them with a list of questions, I was still unsuccessful. However the DETR did provide me with a range of documents that I have found useful for this study. My interviews were therefore restricted to British trade union representatives .

${ }^{8}$ Interview, ITF Official, London: July, 2008.

${ }^{9}$ Crewing costs after fuel costs are the most expensive operating expenses of ship owners.

${ }^{10}$ Cadets refer to officers in training.

${ }^{11}$ The information for this section is sourced from Her Majesty's Revenue and Custom's manual of the tonnage tax scheme (2001) published by Her Majesty's Revenue and Custom office (equivalent of a Department of taxation and customs). The section on calculating tonnage tax profits is a direct extract from the manual (Reference TTM, 2001:1600 of the manual).

12 Interview, NUMAST official, London: June 2008.

Interview, RMT official, London: June 2008.

${ }^{13}$ Interview, NUMAST official, London: June 2008.

${ }^{14}$ Interview, RMT official, London: June 2008. 
${ }^{15}$ Interview, NUMAST official, London: June 2008.

${ }^{16}$ Interview, NUMAST official, London: June 2008.

${ }^{17}$ Interview, NUMAST official, London: June 2008.

${ }^{18}$ Interview, NUMAST Official, London: June 2008.

${ }^{19}$ Interview, RMT official, London: June 2008.

${ }^{20}$ A revealing and informative discussion of the rise and decline of British seafarers in the merchant navy is provided in Tony Lane's 1986 seminal book, Grey Dawn Breaking. British Seafarers in the late twentieth century (1986) published by Manchester University Press. The book is almost a farewell to and acknowledgement of a bygone era when British seafarers dominated the global maritime industry.

${ }^{21}$ Interview, RMT official, London: June 2008

\section{REFERENCES}

Chamber of Shipping Annual Reports $(1996,2005,2006)$ British Shipping Association, London.

Gardener, B., Naim, M, Obando-Rojas, B, \& Pettit, S (1999). The Future of the UK Shipping Industry. Cardiff, Seafarer International Research Centre, University of Cardiff.

Lane, A. (1986). Grey Dawn Breaking. British Seafarers in the late 20th Century. Manchester, Manchester University Press.

McCaskey, S. (2007). Maritime Economics: New Perspectives. Cardiff, Cardiff Academic Press.

McConville, J., Glen, D, \& Dowden, J (1998). United Kingdom Seafarers Analysis. London, The Centre for International Transport Management, London Guildhall University.

Prescott, J.(1999) British Shipping: Chartering a new course. London, Department of Transport, United Kingdom.

Ruggunan, S. (2001). Articulating Agency: A Case study of the strategies of the South African Transport and Allied Workers Union in servicing South African seafarers. Industrial, Organisational and Labour Studies. Durban, University of Natal. MA dissertation: 150pp.

Ruggunan, S. 2009. Global transformation of the contemporary labour market for merchant navy seafarers: Case Studies of Filipino, South African and British seafaring labour markets. Durban, University of KwaZulu-Natal, PhD thesis: 355pp.

Silver, B. (2003). Forces of Labour: Worker's Movements and Globalization since 1870. New York, Cambridge University Press.

Tilly, C., \& Tilly, C (1998). Work Under Capitalism. Colarado, Westview Press.

Tonnage Tax Maritime Report (TTM). (2001). Post Implementation Review of Tonnage Tax. London, Department of Transport: 1-39. 